\title{
Influence of Forest Stand Density on Pinus Sylvestris Roundwood Quality in Even-Aged Mixed Scots Pine Stands in Myrtillosa Mel. Mesotrophic Site Type
}

\author{
Ziedonis Miklašēvičs \\ Rezekne Academy of Technologies \\ State Stock Company “Latvijas Valsts Meži” (Latvia’s State Forests) \\ Rēzekne, Latvia \\ Email: (Ziedonis Miklašěvičs): z.miklasevics@1vm.lv
}

\begin{abstract}
Among different development directions for better forest utilization, the purposefully detailed assessment of wood quality as raw material, faciliating improved wood utilization in manufacturing of traditional roundwood products as well as brand new products, proves to be very perspective. Roundwood quality features substantially differ depending on forest stand geographic location, growing site conditions, tending of forest stands and other circumstances [2], [3], [11]. Therefore, the economical estimation of more important tree species in Latvia should not be based only on scientific conclusions made in other countries, so particular research is needed for this purpose. Pine (Pinus sylvestris) is the most widespread tree species in Latvia, therefore a research work provided the characteristic of round wood obtained from pine tree stem is an actual point from several aspects, as it is necessary;

- to create early prediction models of roundwood quality;

- to plan harvesting purposes;

- to create the data basis of economically more relevant domestic tree species;

- to provide the further development of roundwood quality assessment methods;

- to estimate the competitiveness of Latvia pine timber in the world market

The main goal of study is to work out the quality characteristic of pine roundwood manufactured in final felling sites depending on timber formation damages- bark abrasion caused side drought.
\end{abstract}

Keywords - bark abrasion, side drought, mature stands, medium aged stands, stands at harvesting age. stands above harvesting age.

\section{INTRODUCTION}

In order to ensure sustainable forest management it is very important to know the forest health and viability. The representing quality features like heartwood, sapwood, wood cells e.t.c. characterize the whole tree and its parts. Parametric characteristic of quality features depends on many circumstances. The quality of forest - plantation on the whole and growing trees are mostly affected by growing conditions [5], [6], methods of reforestation [3], [4], tending methods [11], tree bark diseases [1] forest stand density and tree competition [2], [8], [12].

At the same time due to various factors as high forest stand density and natural damage caused by wind-falls and snow breaks a part of forest stands lose their viability and die [11]. Stand damage can be classified according to location as damage to the stem or root system. Stem damage occurs above the root collar while root damage occurs below in the stem or roots "Fig. 1".

The majority of damage to the residual stand occurs during the felling stage when falling trees collide with residual tree stems. The injury can be designed further as a superficial or deep wound depending on its depth. In Picea abies stands, damage suffered almost inevitably leads to decay. In Pinus sylvestris stands, damage suffered leads to side drought with or without decay "Fig. 2". 


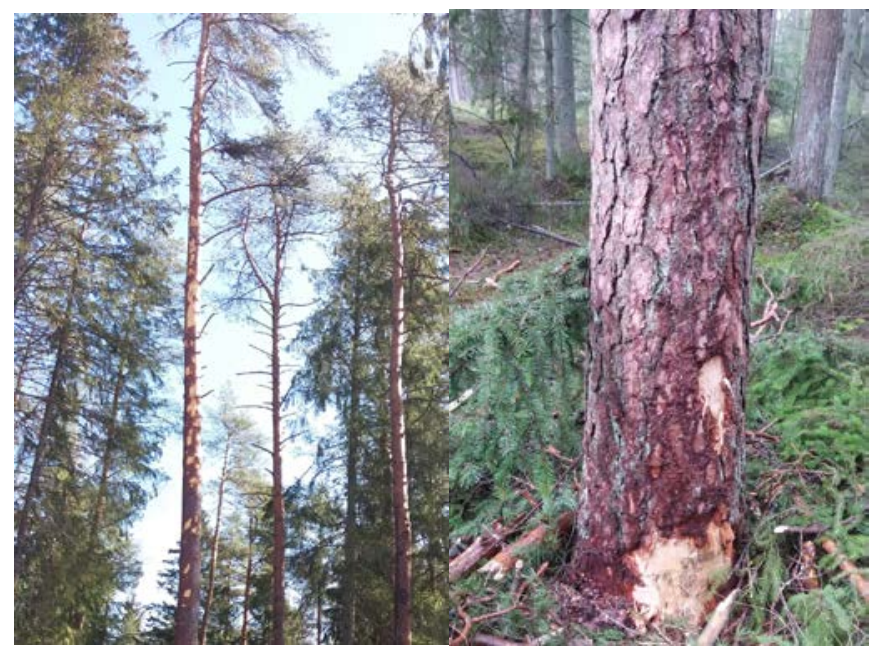

Fig. 1. Stem damage above root collar and root damage caused side drought

Pinus sylvestris stands are more resistant to in stem and can be used mostly as energy wood or pulp heartwood rot but in case of Picea abies the situation wood.

Latvia is really serious-almost a quater of trees have decay
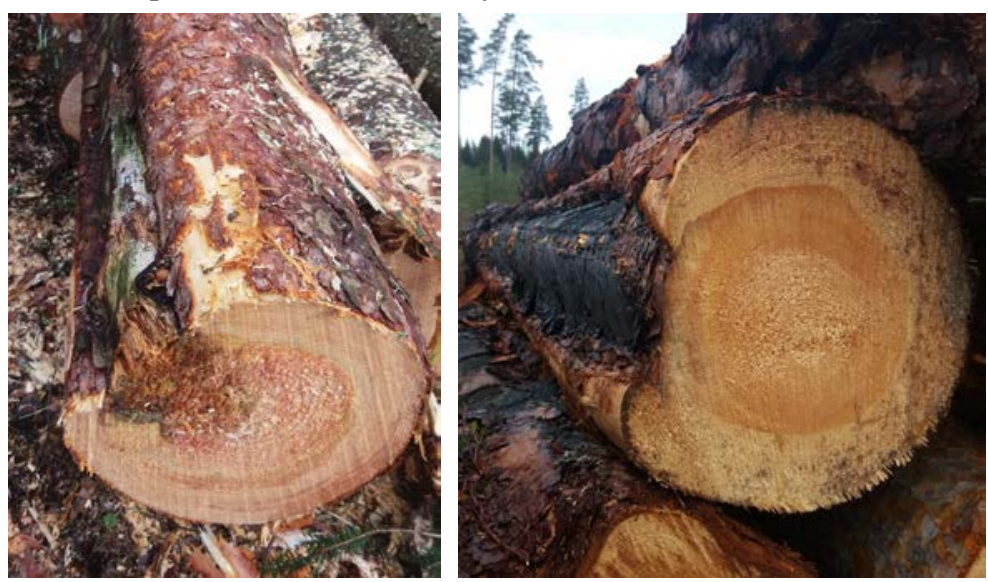

Fig.2. Side drought in Pinus sylvestris stands with and without decay

Harvesting in Latvia has been regulated by legislation [12], which determine the final felling age and diameter according to tree species and soil quality in forest lands. Current Latvian legislation permits the final felling in Pinus sylvestris stands where the trees of the dominant stand have reached the mean age of 101 years or the mean diameter of $35 \mathrm{~cm}$.
Nevertheless by observing the instructions provided in the regulatory dokuments and when final felling in hight stands density has been performing, round timber with high volume features have been harvested, e.g. side drought, sweep e.t.c. which reduce the timber value "Fig. 3”.

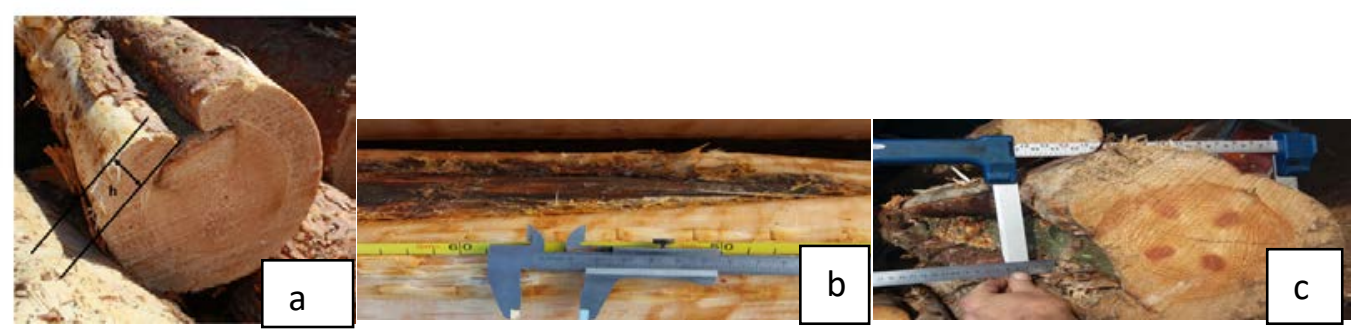

Fig.3. The depth (h) limit of side draught (a) according to the roundwood assortiment's quality requirements: $1 \mathrm{~cm}$ for wood poles (b); $2 \mathrm{~cm}$ for sawlogs (c) 
Pinus sylvestris is the most widespread conifer tree specie in Latvia. According to Latvian National Forest Inventory data (2013-2017), pine stands comprise 856.4 thousand ha or $26.5 \%$ of the total forest area (www.silava.lv; according to forest defination - at least 1000 trees/ha, able to reach the height of $5 \mathrm{~m}$ ).

4.7\% from the total forest area is Myrtillosa and 22\% is Hylocomiosa. The total wood standing volume in Myrtillosa stands (age 101>) reaches $310 \mathrm{~m}^{3} /$ ha and 365 $\mathrm{m}^{3} /$ ha in Hylocomiosa stands, where Pinus Sylvestris standing volume respecxtively $206 \mathrm{~m}^{3} / \mathrm{ha}$ in Myrtillosa and $178 \mathrm{~m}^{3} /$ ha in Hylocomiosa [11].

Because forest that grow today will ensure Latvia with forest resources after several decades, therefore, it is especially important that its value is not decreasing.

\section{STUDY GOAL}

The main task of forestry is the growing forest with its most important indicator - wood resources stored in living trees. In contrast, timber companies have an additional interest not only in the volume of timber harvested, but mainly in the quality indicators of round timber.
Therefore, it is important to predict possible wood defects of growing trees, which may limit the applicability of the produced round timber to high value-added sawn timber, building construction elements, etc. production.

The main goal of study is to work out how the forest stand density at the harvesting age as a most important factor determine Correlation coef $\mathrm{r}=0.66$ at $\mathrm{r}_{0.05}=0.12$ between Pinus Sylvestris stock volume and stand density [11] impacts the quality of roundwood assortiments and to evaluate the damages of side draughts as timber formation damages caused by wind-falls and snow in high forest stand density felling areas of mesotrophic site type ( Myrtillosa mel.)

The following objective was set to achieve the study goal:

To clear up the characteristic of timber formation damage - Side drought in the commercial part of pine stems (10-15m section, devided in 4 zones) harvested as wood poles "type A. Fig.1" in overstockled young stands with overdue thinning where Scots pine current rotation age are older than 101 years and forest stand density higher than 0.7 .

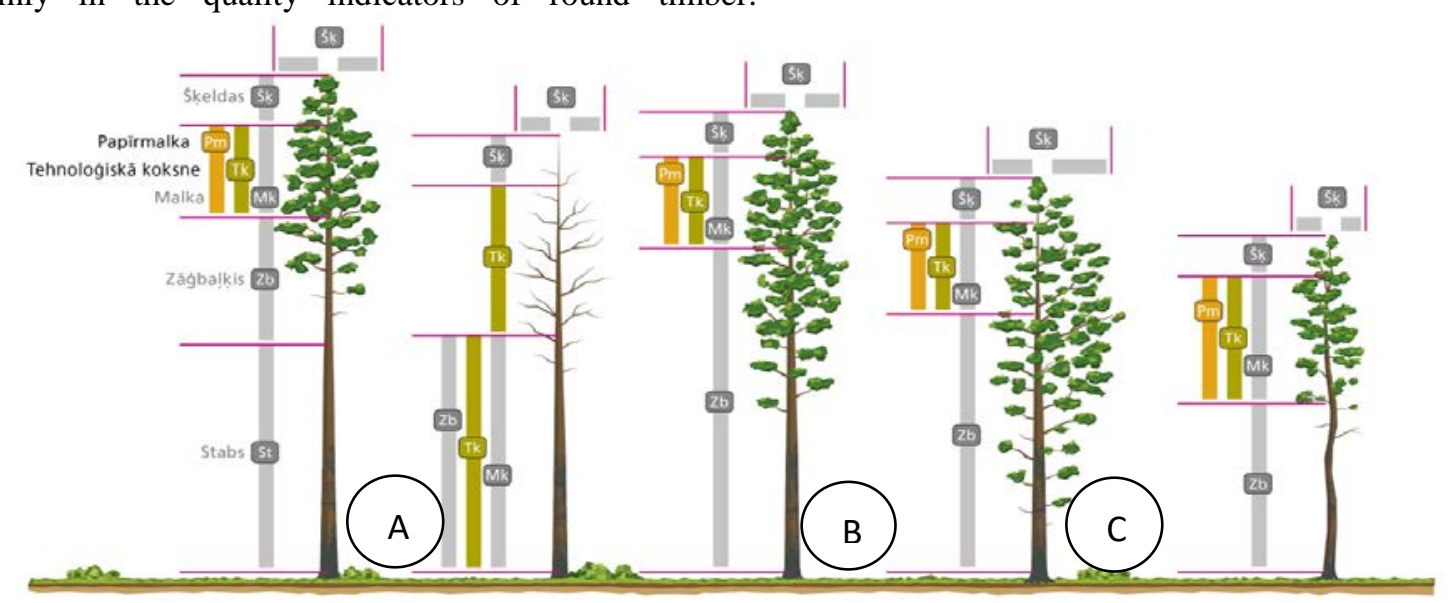

Fig.4. Harvested products from different pine stems types, where: A; B; C -pine stem types, St - wood poles; Zb- saw logs; Pm- pulp wood; Tktechnological wood; Mk- fire wood; Šķ-wood chips

\section{MATERIALS AND METHODS}

A field study was carried out at the period April June of 2020 in Zemgale region of Latvia and in energy company JSC “Sadales tīkli”. Wood poles which were harvested in Myrtillosa mel. forest type where the age of pine stands according to the forest inventory description were more than 105 years old were selected in the investigation. "Table 1."

DATA CHARACTERIZED HARVESTING SITE

\begin{tabular}{|c|c|c|}
\hline \multicolumn{2}{|c|}{ DATA CHARACTERIZED HARVESTING SITE } \\
\hline Woodland type & 1905 & 1900 \\
\hline Regeneration year & MP3E1B11510E85 & 9P1E120+B12010E80 \\
\hline Species & 0.70 & 1.3 \\
\hline Area (ha) & Previous managment operation isn't registred \\
\hline \multicolumn{2}{|c|}{} \\
\hline
\end{tabular}


The average age of trees before harvesting in the felling area was determined by drilling 20-25 trees at the butt swelling using Presler drill and counting the annual rings of increment core.

TABLE 2

\begin{tabular}{|c|c|c|c|c|c|}
\hline $\begin{array}{c}\text { Harvesting site } \\
\text { identification }\end{array}$ & Area (ha) & Amount $\left.\mathbf{( m}^{\mathbf{3}}\right)$ & Species & \multicolumn{1}{c|}{$\begin{array}{c}\text { Harvested } \\
\left.\text { amount } \mathbf{( m}^{\mathbf{3}}\right)\end{array}$} & Stems \\
\hline 493380285996 & 1.99 & 969.03 & Birtch & 31 & 66 \\
\hline
\end{tabular}

Traceability of wood poles was ensured. In order to gather information about impact of side draught on wood pole's quality parameters, the following approach, methods and data was collected:

- data characterized the wood felling area: coordinates of wood felling area; forest type; growing stock; growth conditions; site quality classes; species composition index and the age of species;

data characterized the wood pole's visual quality parameters: lengh of wood pole; wood pole top, butt diameter and diameters measured with the interval $1 \mathrm{~m}$, wood pole diameter at a side draught positions; a side draught possition measured from the wood pole butt and a width/number of annual rings characterized the age of injury.

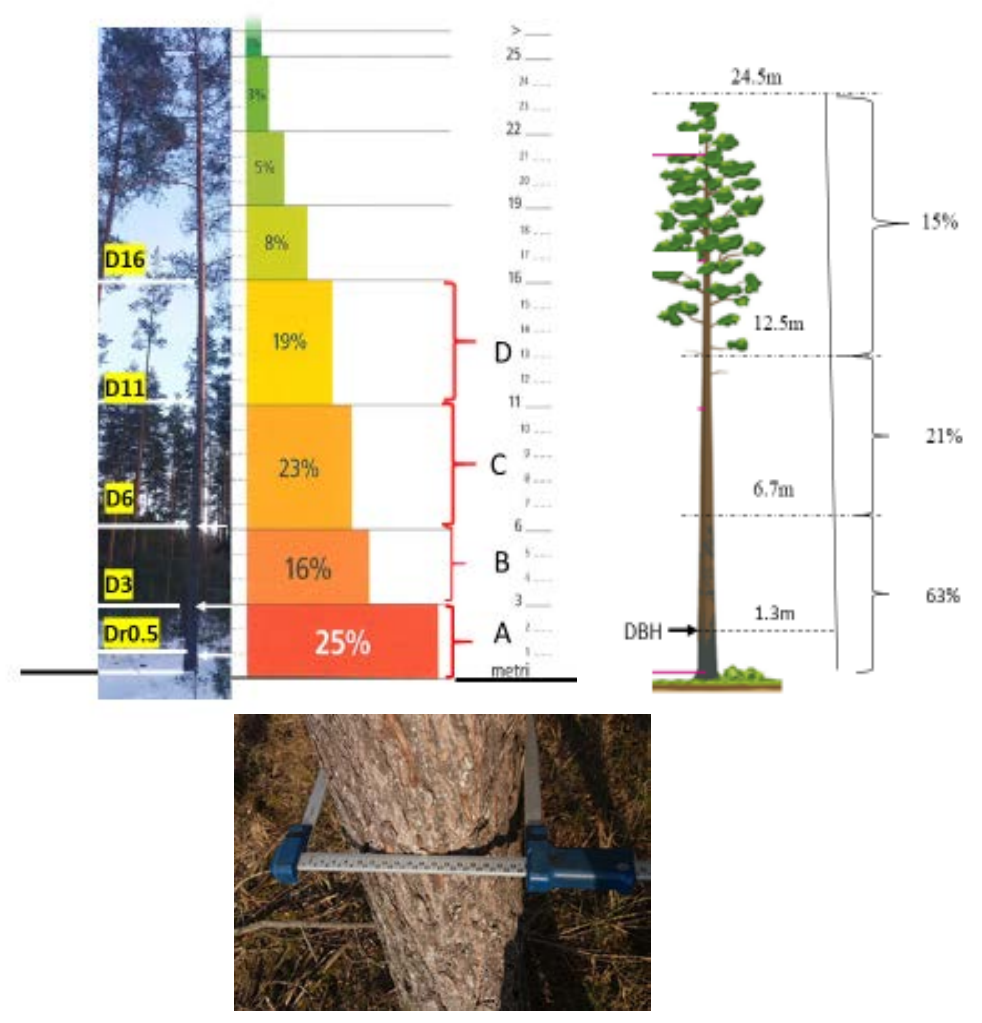




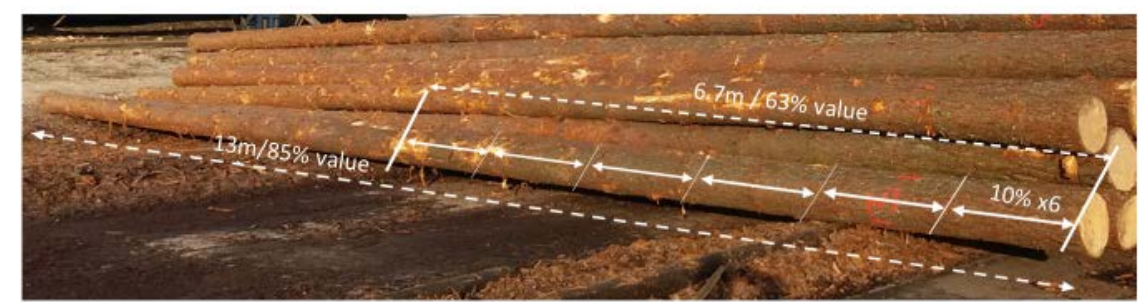

Fig. 5. The methodical distribution of pine stem by volume, zone and by timber value when stem lenght $\mathrm{H}-24,5 \mathrm{~m}, \mathrm{DBH}-36 \mathrm{~cm}$; H/D=0.68

The methodical scheme of the investigation is given in "Fig. 5", where the commercial parts of pine stems manufactured as wood poles are devided in 4 zone which represents more than $84 \%$ of roundwood value.
The quality control of each of harvested 221 pcs. wood poles "Table 3, 4" was done in harvesting sites and JSC "Sadales tīkli" in each stage of technological process.

TABLE 3

\begin{tabular}{|c|c|c|}
\hline Wood poles lenght (m) & $\operatorname{Pcs} / \mathrm{m}^{3}$ & Average 1pcs volume $\left(\mathrm{m}^{3}\right)$ \\
\hline 10 & $48 / 22.14$ & 0.5 \\
\hline 12 & $118 / 72.1$ & 0.689 \\
\hline 13 & $26 / 20.06$ & 0.768 \\
\hline 14 & $29 / 24.80$ & 0.852 \\
\hline Total & $221 / 139.1$ & \\
\hline
\end{tabular}

The data characterized quality of harvested wood poles are given in "Table 4".

TABLE 4

\begin{tabular}{|c|c|c|c|}
\hline THE QUALITY OF HARVESTED WOOD POLES & $\begin{array}{l}\text { \% from harvested } \\
\text { stem }\end{array}$ \\
\hline Quality appreciations & Volume pcs $/ \mathbf{( m}^{\mathbf{3}} \mathbf{)}$ & $\mathbf{\%}$ from harvested volume & 32.94 \\
\hline Defect (Curvature) & $75 / 35.02$ & 25.19 & 18.19 \\
\hline Defect (Side draughts) & $38 / 25.71$ & 56.49 & 48.87 \\
\hline Corresponds to the quality & $108 / 78.27$ & & \\
\hline Total & $221 / 139.1$ & & \\
\hline
\end{tabular}

The measurement example of side draught characterized parameters is given in "Fig. 6". 
Environment. Technology. Resources. Rezekne, Latvia Proceedings of the $13^{\text {th }}$ International Scientific and Practical Conference. Volume 3, 208-215
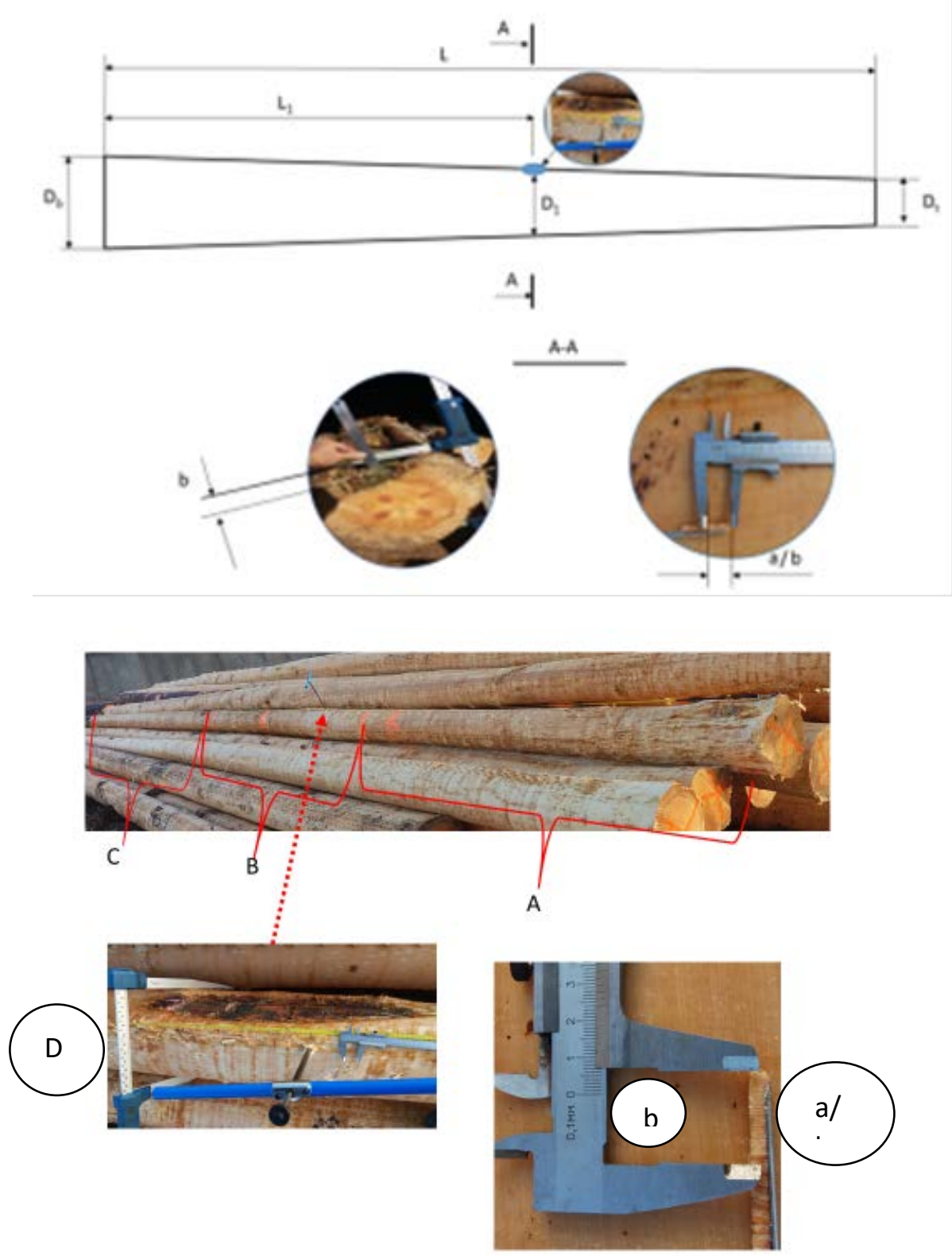

Fig. 6. The measurement example of side draught characterized parameters, where: $A, B$, C-zone of side draught position place; $\mathrm{D}_{1}$-wood pole diameter at side draught position, mm; b- side draught depth, mm; a/b- number/thickness of annual rings characterized the age of injury; $\mathrm{L}_{1}$ - distance of side draught position measured from butt, $\mathrm{cm}$; L- the lenght of wood pole, $\mathrm{cm}$; $\mathrm{D}_{\mathrm{t}}$ - the wood pole top diameter, mm; $\mathrm{D}_{\mathrm{b}} / \mathrm{D}_{\mathrm{b} 0.5}-$ the $\mathrm{wood}$ pole (from B zone) butt diameter / the wood pole (from A zone) butt diameter measured $0.5 \mathrm{~m}$ from the butt, mm

\section{RESULTS AND DISCUSSION}

Harvesting development in Latvia is regulated by Cabinet Regulation No. 935 "Regulations on Tree Felling”, which determines the age and diameter of the main felling according to the dominant tree species and quality. However, following the instructions provided in the regulatory documents and performing felling in forest stands with high density, round timber with an increased amount of wood faults, such as dry sides, curvature is obtained. etc., which reduces the industrial value of timber. With no or delayed felling of such stands in such harvesting sites, the amount of dead wood increases, which exceeds the natural growth. Respectively, the biological value of the forest stand increases, but the industrial value decreases. Various literature sources [11] indicate that the current growth of wood in mature stands is approx. $6.5 \mathrm{~m}^{3} / \mathrm{ha}$, in felling age stands approx. $5.2 \mathrm{~m}^{3} / \mathrm{ha}$. At the same time, the natural growth of the stock in uncultivated stands is close to zero or even negative. The preservation of such stands is in 
Environment. Technology. Resources. Rezekne, Latvia Proceedings of the $13^{\text {th }}$ International Scientific and Practical Conference. Volume 3, 208-215

stark contrast to the tasks of modern forestry - the product produced in logging is defective [9], [14].

According to the methodical requirements the measurement results characterized damages of pine stems caused by side draughts are given in "Fig. 6”, “Table 5”.

TABLE 5

THE MEASUREMENT RESULTS CHARACTERIZED DAMAGES OF PINE STEMS CAUSED BY SIDE DRAUGHTS

\begin{tabular}{|c|c|c|c|c|}
\hline Zone & A & B & $\mathbf{C}$ & $\mathbf{D}$ \\
\hline Diameters & Dr0.5 / D1 / D2 & D3 / D4 /D5 & D6 / D7 / D8 / D9 /D10 & $\begin{array}{c}\text { D11 / D12 / } \\
\text { D13/ } \\
\text { D14/D15 } \\
\end{array}$ \\
\hline \multicolumn{5}{|c|}{ Taper (mm/m) (221wood poles) } \\
\hline Average & \multicolumn{4}{|c|}{7.0} \\
\hline Stdev & \multicolumn{4}{|c|}{0,57} \\
\hline Median & \multicolumn{4}{|c|}{6.89} \\
\hline \multicolumn{5}{|c|}{ Wood pole diameters (mm) measured according to the methodical requirements (221wood poles) "Fig. 2" } \\
\hline Average & $301 / 294 / 288$ & $287 / 280 / 273$ & $267 / 260 / 253 / 246 / 240$ & $\begin{array}{c}237 / 231 / 227 / \\
229 / 223\end{array}$ \\
\hline Stdev & $30 / 30 / 29$ & $26 / 26 / 25$ & $25 / 25 / 25 / 25 / 25$ & $\begin{array}{c}22 / 22 / 21 / 16 / 1 \\
6\end{array}$ \\
\hline Median & 295/288/281 & $287 / 280 / 274$ & $267 / 261 / 254 / 248 / 241$ & $\begin{array}{c}241 / 234 / 231 / \\
233 / 227\end{array}$ \\
\hline \multicolumn{5}{|c|}{ Wood pole diameters (mm) at side draught positions according to damaged zone (38 wood poles) "Fig. 2" } \\
\hline Average & 300 & 265 & 245 & 211 \\
\hline Stdev & 30 & 42 & 40 & 25 \\
\hline Median & 290 & 247 & 252 & 207 \\
\hline \multicolumn{5}{|c|}{ The depth of side draught (mm) "Fig. 2" } \\
\hline Average & 20.4 & 22.1 & 18 & 17 \\
\hline Stdev & 8.6 & 8.9 & 4.8 & 4.1 \\
\hline Median & 21 & 22 & 18 & 15.5 \\
\hline \multicolumn{5}{|c|}{ The width of annual rings (mm) characterized stem wound age "Fig. 2" } \\
\hline Average & 0.98 & 1.09 & 0.91 & 1.06 \\
\hline Stdev & 0.22 & 0.19 & 0.15 & 0.19 \\
\hline Median & 1.10 & 1.15 & 1.08 & 1.11 \\
\hline \multicolumn{5}{|c|}{ Years before side draught damages (mm) } \\
\hline Average & 20.8 & 20.2 & 19.7 & 16.0 \\
\hline
\end{tabular}

\section{CONCLUSIONS AND RECOMENDATIONS}

The results of the study indicated the following:

- $\quad$ About $18.19 \%$ of inspected wood poles (pine stands) harvested in felling areas in Myrtillosa mel. forest type where the mean age of pine trees were 115-120 years old were damaged by timber formation damages -side draughts.

- $\quad$ About 18.49\% from harvested pine stems volume (wood poles ) were rejected due to timber formation damages -side draughts which average depth (mm) exceeds $20 \mathrm{~mm}$.

- $\quad$ The data characterized stem wound age shows that the biological value of the pine stand starts to increase, but the industrial value decreases in mesotrophic site type ( Myrtillosa mel.) harvesting sites where the age of stems is more than 100 year.

- $\quad$ There are advisible to raise the issue of reducing the felling criteria (age of the main felling (in years) depending on the quality and average diameter of the stand) in non-cultivated felling stands in felling stands where there is no purposefully created tree stands structure, by evaluating socio-economic and ecological aspects.

- In forests with this kind of management history the application of the current rotation age (101 years) will likely be a grave mistake. The existing management model should be altered. 


\section{REFERENCES}

[1] N. Arhipova, T. Gaitnieks, J. Donis, J. Stenlid and R. Vasaitis, "Butt rot incidence, causal fungi and related yield loss in Picea abies stands of Latvia”. Canadian Journal of Forest Research, 41 (12 VI.): 2011, pp. 2337-2345.

[2] I. Baumanis, ”A complex research project: factors in Latvia affecting the health of pine (planting stock and young plantations), and recommended protective measures”. Proceedings of the Latvian Academy of Sciences, Section B, 7(552), 1993, pp. 7980.

[3] I. Baumanis, Ā. Jansons and U. Neimane, Selection, genetics and seeding in Latvia. Daugavpils, 2014, p. 324.

[4] R. A. Blanchette. "Decay and canker formation by Phellinus pini in white and balsam fir”. Can. J. For. Res. 12. 1982, pp. 538-544.

[5] C. J. Earle "Pinus sylvestris (Scots pine) description. In: The Gymnosperm Databaswe”.2011, http://www.conifers.org/pi/Pinus sylvestris.php [archived in July, 2014]

[6] D. E. Etheridge "True heartrots of British Columbia. Canadian Forest” Service, Pacific Forest Research Center, Victoria, BC.Forest Pest Leaflet No. 55. 1972, p. 14.

[7] R. S. Hunt and D. E. Etheridge "True heart-rots of the Pacific Region”. Forest Pest Leaflet No.55, Pacific Forestry Centre. 1995, p. 8.
[8] M. J. Larsen and F. F. Lombard, “A new variety of Phellinus pini associated with cankers and decay in white firs in southwestern Oregon and northern California”. Can. J. For. Res. 9: 1979, pp. 31-38.

[9] Z. Lībiete, J. Jansons and T. Zālītis, “Age structure and productivity of conifer stands in Latvia”. Mežzinātne / Forest Science 19(52): 2009, pp. 28-48.

[10] Z. Miklašēvičs, "Evaluation of heartrot caused by Phellinus Pini and related yield loss in pinus sylvestris stands”.// The 12th international conference reports, Rezekne 2019, pp. 166-171.

[11] P. Zālītis and J. Jansons, Structure of purposefully established stands. LVMI “Silava”, 2009, pp. 70-75.

[12] Cabinet Regulations $\mathrm{N}^{\mathrm{O}} 935$. Regulations on tree felling.

[13] Evaluation of the effects of heart rot fungi on live treestructuralstability. https://www.for.gov.bc.ca/.../WTReportEffects-of-HeartRotFungi-June.

https://www.zm.gov.lv/public/ck/files/ZM/mezhi/.../1_pielikums.pdf. [Accessed 2007].

[14] Opinion on the draft guidelines on forest and related development guidelines for 2015-2020, VSS-489 ldf.lv/sites/default/files/faili/Par_mums/LDF_vestules/80_ldf_m snp_vss489.doc [Accessed 2014]. 